\title{
Conceptual Background of Transformative Social-Ecological Innovation
}

In this chapter I survey key theories and concepts that provide substance to the workings of Transformative Social-Ecological Innovation (TSEI). A number of relevant theories and concept have already been mentioned in the previous chapters, such as Social Contract theory (Sect. 3.1), and in Sects. 3.8 and 3.9, including resilience theory and social-ecological systems (Sect. 3.8), quintuple helix innovation model (Sect. 3.9), as well as institutional change and the structureagency debate (Sect. 3.9), and several economic theories (Sects. 3.2 and 3.3). In this chapter I will start with providing a conceptual discussion and definition on Transformative Social-Ecological Innovation (Sect. 4.1), and devote more attention to various theories and approaches that are relevant for TSEI, such as transition studies (Sect. 4.2), institutional design principles for governing the commons (Sect. 4.3), design principles from nature (Sect. 4.4), complex adaptive systems (Sect. 4.5), adaptive, reflexive, and deliberative approaches to governance, management, and planning (Sect. 4.6), social learning, policy learning, and transformational learning (Sect. 4.7), shared value, multiple value creation, and mutual gains approach (Sect. 4.8), effective cooperation (Sect. 4.9), transdisciplinary cooperation, living labs, and citizen science (Sect. 4.10), and the art of co-creation: approaches, principles and pitfalls (Sect. 4.11).

Drawing on the insights from this literature, I argue that studying Transformative Social-Ecological Innovation should involve a look at both structure and agency, in particular at decisive moments where both structure and agency intersect (i.e. in action situations), as well as the resulting outputs, outcomes, and impacts. I identify a critical need for attention to the fundamentally political character of Transformative Social-Ecological Innovation, and the need for multiple value creation, in which parties seek for shared values, mutual gains, and common interest.

The original version of this chapter was revised. Incorrect citation of Fig 4.5 in page 100 has been corrected to read as Fig. 4.3. The correction to this chapter is available at https://doi.org/10.1007/ 978-3-030-67130-3_9 


\subsection{Definition of Transformative Social-Ecological Innovation (TSEI)}

In this section I introduce the concept of Transformative Social-Ecological Innovation (TSEI), as a response to the limitations of more traditional and anthropocentric notions of social innovation, in particular when applied to sustainability issues.

Social innovation is not a new idea but has become immensely more popular in the past two decades, not least because traditional models of innovation-targeting technological innovation-often fall short in a world of complex societal challenges. A technological innovation with social impact is, therefore, not the same as a social innovation. Social innovation mainly consists of new forms of governance, organization, management, participation, and cooperation within and between government, businesses, citizens, civil society organizations, and research and education institutions.

Within the Social Sciences, there are various definitions of social innovation. Haxeltine et al. (2016:20) define a social innovation (SI) as a change in social relations, ushering in new ways of thinking, doing, and organizing. If this social innovation can also bring about a systemic change in a specific context, it is called a Transformative Social Innovation (TSI). Transformative Social Innovation (TSI) is conceptualized as social innovation that challenges, alters, or replaces dominant institutions in the social context (Haxeltine et al. 2016). Another definition is provided by Moulaert et al. (2013), in which social innovation is transdisciplinary and defined as a social, innovative process, along with its outcome, that contributes to:

- fulfilling human needs;

- creating and strengthening social relationships;

- enhancing the socio-political capacity of citizens.

Several points of criticism can be levelled at this definition, however, such as a one-sided focus on human needs. In contrast, for addressing sustainability issues, the intricated coupling between human and biophysical systems needs to be recognized. In other words, it is not only about human needs but also about the needs of nature, life-supporting ecosystems, and our planet, on which humans depend. Enhancing the socio-political capacity of citizens, in Moulaert's definition, is also one-sided, as social innovation is not only about 'citizens' capacity', but about enhancing 'society's capacity' to innovate, which involves effective cooperation between multiple parties within society (see quintuple helix innovation model in Sect. 3.9).

Haxeltine et al. (2016) moreover criticize a definition of social innovation that also describes the outcome, because this can lead to processes in which the destination transcends the journey towards it. To avoid this, they define social innovation as a process rather than as a result.

The Dutch Advisory Council for Science and Technology Policy (2014) defines social innovation as: 'New solutions (products, services, models, markets, processes, 
etc.) that simultaneously meet a societal need (more effectively than existing solutions) and introduce or improve capacities and relationships and a better use of resources'. In other words, social innovations are good for society and increase its capacity for action.

When applying the concept of social innovation to sustainability issues, it becomes clear that the concept, by definition, is limited by its anthropocentric approach, instead of recognizing the intricate coupling of human and biophysical systems. In none of the above anthropocentric definitions there is a mention of ecosystems, neither an acknowledgement of the relation between social, economic, and ecological systems. At best, (natural) resources are considered to be used exclusively by humans, to serve the needs of humanity, as in the definition by the Dutch Advisory Council (2014), which reserves a central place for the 'societal need'. Olsson and Galaz (2012), therefore, argue that addressing only the social dimension will not be sufficient to guide society towards sustainable outcomes. Within this debate, the concept of eco-innovation was introduced by René Kemp and Peter Pearson (2007) as a valuable contribution to better understand innovation targeted at solving sustainability challenges. In the literature, the term eco-innovation is generally understood to mean 'the production, application, or exploitation of a good, service, production process, organizational structure, or management or business method that is novel to the firm or user and which results, throughout its life cycle, in a reduction of environmental risk, pollution, and the negative impacts of resource use (including energy use) compared to relevant alternatives' (Kemp and Pearson 2007).

As a response to above anthropocentric definitions, and in addition to the concept of eco-innovation by Kemp and Pearson (2007), Per Olsson and Victor Galaz (2012) introduced the concept of Social-Ecological Innovation, which is defined as 'social innovation, including new technology, strategies, concepts, ideas, institutions, and organizations that enhance the capacity of ecosystems to generate services and help steer away from multiple earth-system thresholds'. Although this definition by Olsson and Galaz does acknowledge the intricate coupling between social and ecological systems, it does not explicitly mention the fundamental and systemic changes that are required in social and economic systems, such as a transition to regenerative and circular economies and cultures, in order to realize a sustainable and regenerative society. Hence, this definition could be improved by adding an explicit recognition for the need of systemic innovation, defined as 'profound transformations in social systems', which involve 'changes in established patterns of action as well as in structure, which includes dominant cultural assumptions and discourses, legislation, physical infrastructure, the rules prevailing in economic chains, knowledge infrastructure, and so on' (Grin et al. 2010).

Following from above, in this book I propose to complement and redefine the concept of Social-Ecological Innovation (SEI) by Olsson and Galaz (2012), with the concept of Transformative Social Innovation (TSI) by Haxeltine et al. (2016), resulting in the concept of 'Transformative Social-Ecological Innovation' (TSEI). This concept is applicable to systemic innovations in social-ecological systems related to water, food, energy, biodiversity, climate change, health, spatial planning, 
mobility, and built environment, as well as a transition to regenerative and circular economies and cultures. The overall goal of TSEI would be to realize a Natural Social Contract that promotes human security, social justice, and planetary health (see Sect. 3.8).

Following the above reasoning, I define Transformative Social-Ecological Innovation as 'systemic changes in established patterns of action as well as in structure, including formal and informal institutions and economies that contribute to sustainability, health, and justice in all social-ecological systems' (definition by author). It is about society re-asserting a sustainable, regenerative, and healthy future. To avoid confusion about the term 'institution' I use the definition proposed by Calhoun (2002, p.33): 'Institutions are deeply rooted patterns of social practices or norms that play an important role in how society is organized'. Institutions can pertain to various areas of social activity, such as family life, associations, and politics. Generally speaking, institutions result from a process of institutionalization, in which preferences are gradually strengthened until they are fixed and familiar. This process is usually accompanied by conflicts and the exercise of social power (Parker et al. 2003). Following the definition of Calhoun (2002) I distinguish between formal and informal institutions, where the first includes the constitution, laws, and legislation, and the latter includes customary law, existing practices, norms, and culture (see also Sect. 5.2).

The definition of Transformative Social-Ecological Innovation (TSEI) proposed here is in line with the critical tradition of social innovation within sociology, which argues that such innovations aid in a transition away from the current regime rather than lead to reforms within it. Contrary to this sociological interpretation, an increasingly economic interpretation of social innovations has gained ground in recent years, which primarily defines social innovation as an instrumental, helpful tool to ensure the continuation of common developments by improving what already exists (Dagevos 2018). In this sense, social innovation is absorbed into the prevailing paradigm, ridding social innovation of its rebellious, socially critical character, as well as its transformative power (ibid. 2018). For paradigm shifts such as the sustainability transition, it is important that Transformative Social-Ecological Innovations remain 'radical'. This, however, can be very difficult to accept for a great many parties, i.e. the powers that be. Consequently, issues of distribution and power play an important role in societal transformation processes (Meadowcroft 2009; Cattacin and Zimmer 2016; Karré 2018; Huntjens 2019), because it involves several groups, each of which have their own norms, values, and interests. This also brings mechanisms of inclusion and exclusion into play (Sassen 2014), which can lead to conflicts and lawsuits. It will always be a battle to overcome vested interests, change existing systems and paradigms. In Sects. 4.1 and 5.3, I will follow-up on the critical need for attention to the fundamentally political character of Transformative Social-Ecological Innovation, and the need for multiple value creation, in which parties seek for shared values, mutual gains, and collective well-being in a socialecological setting. 


\subsection{Transition Studies}

For more than 20 years, transition studies have been an interdisciplinary research field focusing on the complexity of changes in systems in society. It is interdisciplinary because the field takes a holistic approach to analysing society, including social, cultural, institutional, technological, ecological, economic, and political aspects. Transition theory is particularly useful in identifying solutions to wicked policy problems (Avelino et al. 2016, p. 557; Rittel and Webber 1973). These problems are so persistent that inter-party cooperation is essential if a solution is to be found. Clashes of values are inevitable, as the sustainability transition calls for fundamental changes to be made in different layers of society. At the same time, the power to influence this process will often be divided among several actors who may perceive problems differently (Grin et al. 2010; Kemp et al. 2007, p. 316).

The field of transition studies has brought forth a multitude of theoretical frameworks, such as the Multi-Level Perspective (MLP) model, a theoretical framework for analysing systemic transitions over an extended period of time (20-40 years) (Geels 2011; Geels and Kemp 2000; Smink 2015). See Fig. 4.1.

The MLP states that transition arises as a consequence of interactions between three analytical levels. At the micro-level, innovative practices, or niche experiments, emerge. These are innovative social, economic, technological, or policy practices that are different from and often protected from the dominant regime. The concept of a niche can be equated to that of social innovation when both provide a collective, new solution to a societal problem or social need. In practice, the meso-level is most often the structural context of such developments, encompassing the dominant culture, formal and informal rules, routines, knowledge, and infrastructure that perpetuate a particular practice.

At the meso-level, for instance, it is interesting to explore TSIs implemented by the regime/powers that be. The macro-level is the landscape on which major changes take place in terms of politics, culture, and worldviews, e.g. globalization and individualization, or natural features that can be difficult to influence and tend to change slowly. Landscape developments are the result of the ideas and actions of large numbers of players, as it takes very long for actors to influence the landscape because of its tendency for slow change. Examples include demographic and economic trends and political ideologies (Geels and Schot 2007; Loorbach and Rotmans 2006), as well as ecological processes and major disasters such as Fukushima, and the impact they have on the system.

The chances of and possibilities for systemic changes increase as the regime starts to experience more pressure from the landscape and niches, which may ultimately open up a window of opportunity. Once a niche is sufficiently developed it can break through in the regime. When a niche or social innovation can bring about a systemic change, it is often called a Transformative Social Innovation (TSI), systemic innovation or transition. However, transitions are rare because they require exactly the right interaction between the landscape, regime, and niche (Grin et al. 2010, p. 328). 


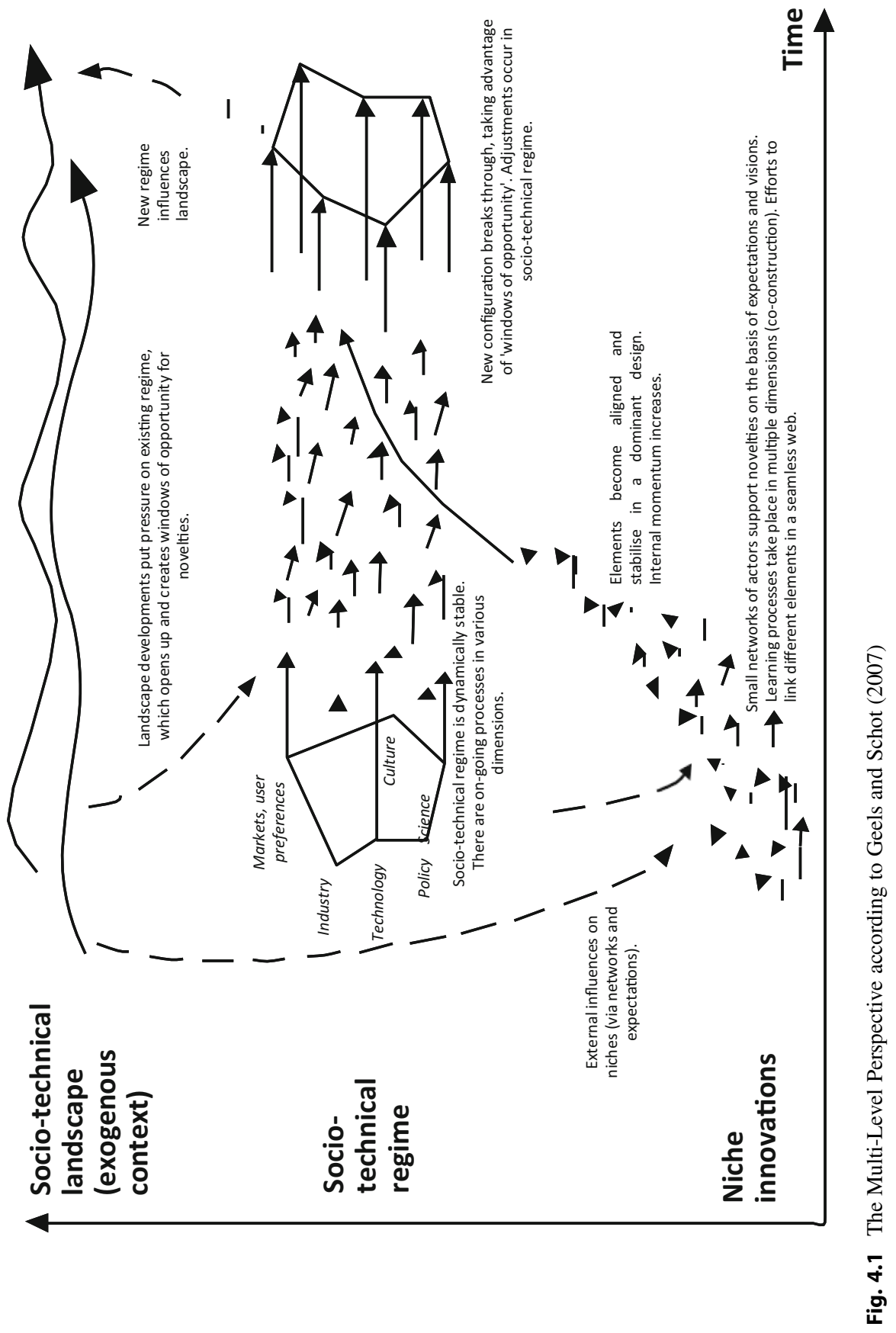


According to Grin, stating that only landscape pressure has the capacity to change policy is overly simplistic. After all, the very politics behind the emergency of new policy and the regime change are crucial if we are to properly understand transitions (Grin 2011, p. 7). Moreover, attempts to change established patterns always come up against resistance, rigidity, and/or normative questions as to the legitimacy, justness, methods, and direction of the transition (Grin 2016, p. 112; Meadowcroft 2009).

Within transition studies, we can distinguish several different governance approaches and philosophies, including:

1. Strategic niche management (Kemp et al. 1998).

2. Transition management (Rotmans et al. 2001; Loorbach 2010).

3. Reflexive governance (Voß and Bornemann 2011).

Whereas strategic niche management (SNM) focuses more on developing new innovations, transition management (TM) is more geared towards strategic interventions implemented by and within the established order. TM is a governance paradigm that sees complexity and uncertainty as drivers of social innovation rather than regarding them as difficult obstacles that must be controlled or managed. Since 2000, TM has been a widely used policy strategy in Dutch ministries. The governance perspective places greater emphasis on policy and the political process within transitions than the other versions do (Grin et al. 2010; Loeber 2003; Rotmans et al. 2001), thereby providing relevant insights for research on Transformative SocialEcological Innovation (TSEI) conducted by this research group. SNM and TM are both concrete governance philosophies, with TM going even further than SNM. Both philosophies go very far in creating perspective for action, though they are sometimes criticized for their somewhat 'modernist' character. Reflexive governance and reflexive monitoring are much more modest in this respect, are less based on control, and are not as clearly designed with an eye on MLP.

Several academics have criticized MPL and TM for ignoring the politics behind transitions (Avelino et al. 2016; Kern and Alber 2006; Meadowcroft 2009). In recent years, however, multiple articles have been published that have included power in their description of the dynamic transition process (Avelino et al. 2016; Avelino and Rotmans 2009; Hendriks and Grin 2007; Kern and Smith 2008; Meadowcroft 2007, 2009; Shove and Walker 2007). Meadowcroft (2009, p. 329) believes it is risky for policymakers to underestimate the political dimensions of transitions. It must be noted, of course, that this is often a difficult task for policy officers because they are executive officers, while elected officials usually determine the (political)goals. There is always a normative aspect to the goal of a transition (see Sect. 3.8). What direction should society take? A good example is the modernization of agriculture in the twentieth century, which many people believed to be a worthwhile objective. However, the agricultural industrialization would later go on to cause problems due to monocultures and the use of pesticides (Hendriks and Grin 2007). Ultimately, the direction of this 'agricultural modernization' was not 'neutral' or 'technically optimal' as much as it was a political choice. In much the same way, the transition to 
climate-proof cities will raise normative questions on what makes cities climateproof and who should bear the costs involved in the process (Eriksen et al. 2015).

According to Meadowcroft, social and political conflict about the nature and direction of a transition are inevitable, if only because priorities will have to be set and government budgets are limited, although the government can also use legislation to steer developments in the right direction. Moreover, everyday cultural and political phenomena also play a role in determining which policy choices are made (Meadowcroft 2009, p. 326). When normative conflicts and conflicting interests provoke discussion, the aforementioned political dimensions of transitions can be seen clearly.

Grin has taken Meadowcroft's criticism to heart, adapting his approach to the practical aspects of policymaking with concepts such as reflexive governance and dual-track governance (Avelino et al. 2016; Grin 2016; Hendriks and Grin 2007). These methods were designed to help policymakers take the political dimensions of transitions into account and to respond to them strategically. Reflexive governance helps actors to critically reflect on (the process of) their desired transition. Dual-track governance discusses how actors can make strategic connections between the different levels (Hendriks and Grin 2007).

\subsection{Institutional Design Principles for Governing the Commons}

Commons are natural or cultural resources that are available to all members of a group or society, such as shared fishing waters, forests, and agricultural land, as well as sources of information, knowledge, and culture. Increasingly, citizens and local organizations are opting for joint management of commons instead of private ownership. In many instances, the joint management of commons is considered as a kind of correction mechanism for the economic climate of liberalization, privatization, and individualism in recent decades. However, it is quite unlikely that in advanced societies, resource users will be able to govern their exploitative action all by themselves, without the help of other socio-political agents and agencies, including the state.

The problem of the commons today is that we still tend to think of it as a common resource, whether it be oceans and rivers or fish stocks and grazing lands or neighbourhoods and cities or the Internet and social media. This is a misunderstanding. Because the joint and sustainable management of commons cannot succeed without institutions for collective action. Elinor Ostrom argued that the commons require a set of rules. She won the Nobel prize in economics for proving that these resources need not succumb to the so-called tragedy of the commons (exploitation by someone taking more than their share) if a system of checks and balances prevails.

In 1990, Elinor Ostrom published eight institutional design principles for the joint, sustainable management of commons. Ostrom defines commons as a social practice of governing a resource not by state or market but by a community of users 
that self-governs the resource through institutions that it creates. Ostrom spent her entire life collecting evidence about the management of commons all around the world, and her research provides convincing evidence that people can succeed to sustainably manage public goods. Ostrom has demonstrated that self-organizing communities can, indeed, manage common pool resources in a sustainable fashion and does not necessarily need to be regulated via a central governing mechanism. Ostrom's work generated an approach that can be used in the analysis and design of effective institutions (or instruments) to manage not just common pool resources but many different types of shared resources (Foster and Iaione 2018).

According to Ostrom, there are 8 institutional design principles for the sustainable management of shared resources:

- Clearly defined boundaries (what are the commons and who own them).

- Adaptation to local conditions.

- Joint decision-making by owners.

- Supervision by or on behalf of the owners.

- Penalties for misuse.

- Low-cost and easily accessible arbitration in the event of disputes.

- Community self-management and recognition by higher authorities.

- For large-scale commons, a layered system with local groups.

Many studies have since explicitly or implicitly evaluated these design principles. Ostrom's first principle, for instance, pertains to the demarcation of clear boundaries around a community of users and the system of resources that this community uses (Agrawal 2002), and has been the principle to attract the most, mainly theoretical, criticism (Cox et al. 2010). The primary complaints about this principle target its excessive rigidity, stating that social or geographical boundaries cannot or need not be defined very clearly in most systems, mainly to allow for more flexible, ad hoc arrangements between participants (ibid.).

Huntjens et al. (2012) show that dealing with complex societal challenges, such as climate change adaptation, requires a number of adapted and additional design principles, including a robust and flexible process, adaptive planning and mechanisms for social learning and policy learning. Table 4.1 presents a brief overview of these adapted and additional design principles (ibid.), which correspond to elements of sustainability learning (see, for example, Beers et al. 2016). Further research is needed in order to test principles on their usefulness and to make them more applicable to TSEI. Empirical research by Termeer et al. (2013) and Runhaar et al. (2017) shows the potential and pitfalls of self-organization and the sustainable management of agricultural and natural land by agricultural cooperatives in the Netherlands, emphasizing the complicated and ambivalent nature of interactions between farmer cooperatives, nature organizations, and government.

Emphatically, these design principles are not a blueprint for action, but have been formulated in such a way that they can be adapted to local and regional contexts of specific geographies, ecologies, economies, and cultures. For example, is it possible to apply these institutional design principles to cities to rethink the governance of 
Table 4.1 Institutional design principles relevant for TSEI aimed at sustainable management of shared resources, such as community-supported agriculture (based on Huntjens et al. 2012 and Ostrom 2005)

\begin{tabular}{l|l}
\hline Institutional design principle & Explanation \\
\hline $\begin{array}{l}\text { Adaptive, reflexive, and deliberative } \\
\text { approaches to governance }\end{array}$ & $\begin{array}{l}\text { Governance taking account of ambivalence, complexity, } \\
\text { uncertainty, and distributed power in societal change. }\end{array}$ \\
\hline $\begin{array}{l}\text { Equal and fair (re-)distribution of } \\
\text { risks, costs, and benefits }\end{array}$ & $\begin{array}{l}\text { Through the involvement and strong representation of } \\
\text { groups and stakeholders who will be affected or are } \\
\text { particularly vulnerable. }\end{array}$ \\
\hline $\begin{array}{l}\text { Arrangements for collective } \\
\text { decision-making }\end{array}$ & $\begin{array}{l}\text { To enhance the participation of groups and stakeholders } \\
\text { in decision-making processes. }\end{array}$ \\
\hline Reflexive monitoring & $\begin{array}{l}\text { This provides a foundation for reflection and social } \\
\text { learning, while at the same time supporting } \\
\text { accountability. }\end{array}$ \\
\hline $\begin{array}{l}\text { Conflict prevention and resolution } \\
\text { mechanisms }\end{array}$ & $\begin{array}{l}\text { Prevention and resolution of conflicts is possible through } \\
\text { a variety of mechanisms, such as appropriate benefit } \\
\text { sharing arrangements, mutual gains approach (see Sect. } \\
\text { 4.8), timing and careful sequencing, transparency, } \\
\text { building trust, and sharing or clarifying tasks, powers, } \\
\text { and responsibilities. }\end{array}$ \\
\hline $\begin{array}{l}\text { Embedded activities/polycentric } \\
\text { governance }\end{array}$ & $\begin{array}{l}\text { Governance and management at a level of scale that does } \\
\text { the most justice to the complexity of socio-ecological } \\
\text { systems. For example, in European law this is similar to } \\
\text { the principle of subsidiarity: social and political issues } \\
\text { should be addressed at the most immediate or local level. }\end{array}$ \\
\hline Policy learning & $\begin{array}{l}\text { By exploring uncertainties, considering alternatives and } \\
\text { 'reframing' problems and solutions, as well as policy } \\
\text { experimentation: a deliberate and coordinated activity } \\
\text { (e.g. pilot projects) to develop and test new policy } \\
\text { alternatives. }\end{array}$ \\
\hline
\end{tabular}

cities and the management of their resources? The answer is negative, since these principles cannot be simply copied to the city context without significant modification. Hence, it is important to stress that design principles such as those presented here are never interpreted or used as a panacea, as they are primarily intended to create more insight into and awareness of various aspects of collective action, though they can be used in practice as entry points for the organization and support of social innovation, collective action, and multi-party collaboration.

For the sustainable management of shared resources the institutional design principles for governing the commons are increasingly being used in various ongoing sustainability transitions, as highlighted in Chaps. 6 and 7. Examples within the food transition include food networks, citizens' farms, community-based agriculture, and short food chain initiatives, in which farmers and consumers work together to produce their own food without relying on wholesalers and supermarkets (see Sects. 6.3 and 6.4). Similar developments can be observed in the urban context, where the concept of 'urban commons' is gaining popularity (Colding et al. 2013; Bollier and Helfrich 2015; Foster and Iaione 2018). 'This constitutes a growing number of urban commons showing that it is not only possible but highly attractive to create 
commons through which citizens can actively participate in the design of their city spaces and the programmes and policies that govern them' (cf. Bollier and Helfrich 2015). However, Foster and Iaione (2018) argue that Ostrom's principles cannot be simply adapted to the city context without significant modification. First of all, natural commons (e.g. fish stock, forests, or grazing lands) are different from urban commons (e.g. community gardens, parks, neighbourhoods, urban infrastructure, or the whole city as a commons). After analysing 200 urban commons in 100 cities, Foster and Iaione (2018) propose 'a set of design principles that are distinctively different from those offered by Elinor Ostrom and which can be applied to govern different kinds of urban commons, and cities as commons'.

From a commons perspective, a number of fundamental and systemic questions can be postulated to ongoing transitions, such as the transition to a sustainable and healthy agri-food system (Chap. 6) and the urban sustainability transition (Chap. 7). Some examples of such questions include:

- What if agricultural land or city spaces would be managed as a public commons, with user rights instead of property rights? Could this avoid land speculation and selling land to the highest bidder only? Could this avoid excessive mortgages and financial risks for farmers and food pioneers? And would it result in a more sustainable management of shared resources, with fair prices for the services provided by those commoners? For instance, how can we pay a fair price for food products and producers in a society that expects sustainable food production, which at the same time contributes to public health, animal welfare, climate change adaptation and mitigation, biodiversity, nature conservation, etc.?

- How does a group or a community, who's members are in an interdependent situation, organize and govern themselves to obtain continuing joint benefits from the collective management of commons? In this book the example of the regional cooperative 'Land of Values' (In Dutch: LandvanWaarde) is highlighted in Sect. 6.3. And what is the role of government given this self-organizing capacity of commoners? 'The task of governments in contemporary, complex societies is to influence social interactions in such a way that political governing and social selforganization are made complementary' (cf. Kooiman 1993, p. 256), and from this perspective it is perhaps more realistic and effective to co-govern, in particular within a heavily regulated policy field such as agriculture (e.g. see Termeer et al. 2013). From a governance point of view, the challenge is to formulate a role for the government, which encourages rather than discourages self-organizing activity.

\subsection{Design Principles from Nature: Benchmarks for a Natural Social Contract}

Seeing a Natural Social Contract as the object of this book, it is only logical to pay extra attention to design lessons from nature. From an analytical perspective, these natural design principles can be used as a benchmark for a transformation towards a 
sustainable, healthy, and just society. The insights presented in this chapter, and particularly those pertaining to complex adaptive systems (Sect. 4.5) and adaptive governance, management and planning (Sect. 4.6), as well as the institutional design principles for sustainable management of commons (Sect. 4.3) are, in many respects, similar to design lessons taught by nature, such as adaptive capacity, resource efficiency, circularity, and self-organization. This, however, is hardly surprising when we consider that most of the literature reviewed here came from the field of ecosystem management (Holling 1978; Walters 1986; Pahl-Wostl 1995; Lee 1999).

In 1997, Janine M. Benyus published the book 'Biomimicry: Innovation Inspired by Nature', in which she introduced the concept of biomimicry, translating lessons from nature into our daily lives, to a wider audience. In the two decades since her book was published, the concept of biomimicry has gained in popularity, as has, more recently, the interest in biomimicry in the context of social innovation, with the aim of creating products, processes, and policies that are well-adapted to life on earth in the long term. Benyus defines biomimicry as 'a new science that studies nature's models and then imitates or takes inspiration from these designs and processes to solve human problems, e.g. a solar cell inspired by a leaf' (Benyus 1997).

While recognizing the revolutionary character of biomimicry as a design concept for human systems of production, Mathews (2011) argues for a deeper philosophy of biomimicry. It is not only about our production systems that need to be adapted, but also our consumption patterns, labelled by Mathews (2011) as 'psychocultural patterns of desire'. Mathews argues that biomimicry will remain limited as a pathway to sustainability when acting only in imitation of nature, but requires acting from within the mindset of nature.

Within a Natural Social Contract, biomimicry should not be taken as an 'imitation' of life as much as a 'return' to natural, sustainable behaviour by humankind as a component of a greater ecosystem, that of planet earth. However sad this observation may be, the concept of biomimicry alone confirms that humankind lost its way at some point and stopped seeing itself as something 'natural', to the point that we are now forced to mimic nature in order to survive as a species and to ensure the planet remains liveable for future generations. That is why I would argue that a Natural Social Contract does not constitute mimicking nature, but rather constitutes a return to our origins.

Biomimicry is based on Life's Principles (see Fig. 4.2), which are certain design lessons from nature based on general patterns and strategies found among the myriad species that live and flourish on earth. Similar to biomimicry, a Natural Social Contract assumes that all life on Earth is interconnected and interdependent, as well as dealing with the same set of conditions (sunlight, water, gravity, cyclical processes, complex systems, non-linear feedback loops, etc.). Life on Earth has developed a series of strategies over the past 3.8 billion years that are optimized for these conditions and to enable life. For instance, there are innumerable strategies in nature to use scarce resources in a smart way. By learning from these natural design lessons, we can develop innovative strategies and test our institutional and economic system designs against these sustainability benchmarks. 


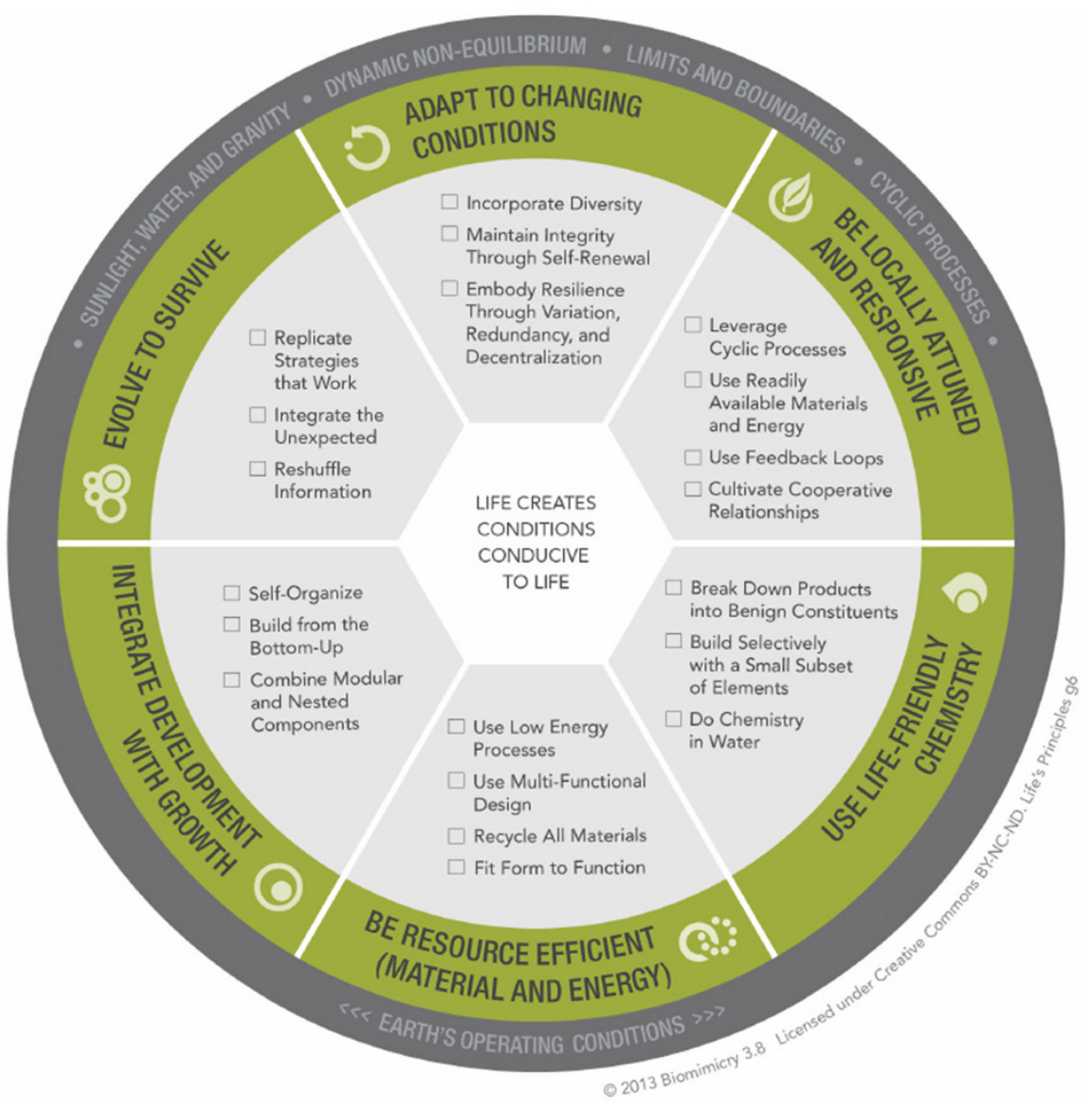

Fig. 4.2 Design principles from nature (Biomimicry 3.8, 2013)

For instance, there are innumerable strategies in nature to use scarce resources in a smart way. Circular Economy and Regenerative Economy are examples of economic design based on ecology, where nature shows how circularity is usually organized at the lowest possible level. For companies it will require a fundamental shift from linear to circular business models. In this respect, a company could be compared with an organism in an ecosystem. When the system changes, it is smart to take a close look at energy, water, and material flows. This offers opportunities for a company to save money, innovate, and deploy new strategies. Or the company could even fulfil a whole new function within the economy. In nature, there are many animal species that break down organic material such as dead leaves into humus. The organic material is broken down by the bugs so far that the trees can take up the raw materials from the humus again and reuse them to make new leaves. Recycle companies in a circular economy have a similar function. However, there are not that many types of it. A large part of our clothing, furniture, electronics, and 
our food ends up at a dumping ground for waste or is incinerated, while it still contains a lot of valuable raw materials. Much more can be done, but getting there requires technological and social innovation, including organizational and institutional innovation. The ratio between the impact of technology and social innovation for realizing a circular economy is estimated at 25:75 (Jonker et al. 2018). Table 4.2 below provides some illustrations of where natural design principles could be translated into, or used as an inspiration for, various types of innovations that support a sustainable, healthy, and just society.

\subsection{Complex (Adaptive) Systems}

All systems that comprise a multitude of interlinked, heterogeneous components are, in fact, complex systems, such as ecosystems, cities or countries, organizations, organisms (e.g. animals, your own body, and your brain), markets, and sectors such as agriculture, healthcare, and education. As such, complex systems are a pervasive feature of the world in which we live (Van der Steen et al. 2011).

Some general characteristics of these complex systems include (Cilliers 2000):

- Complex systems consist of a myriad elements that may, individually, be simple.

- These elements engage in dynamic interaction by exchanging energy on information.

- These interactions are non-linear, as is the system's behaviour as a whole, which means they have a high degree of unpredictability.

- Complex systems are emergent: new properties, patterns, regularities, and/or completely new entities are created through interaction.

- There are many direct and indirect feedback loops.

- Complex systems are open systems: they exchange energy or information with their environment.

- Complex systems have memory, not in a specific place, but distributed throughout the system. Each complex system, therefore, has a history and an evolutionary character, which helps determine how the system behaves.

- The system's behaviour is determined by the nature of the interactions within it, not by what is in its components. Because the interactions are rich, dynamic, part of a feedback loop and, above all, non-linear, the system's behaviour as a whole cannot be predicted by analysing its components.

- Complex systems are adaptive. They can reorganize their internal structure without requiring external intervention.

Transitions in societal systems, such as in food, water, energy, healthcare, mobility, or education, all involve complex adaptive systems (CAS). Complex systems are considered adaptive when their interconnected components can adapt and 'learn' from previous experiences and the system's surroundings (Holland 2006). Such complex adaptive systems (CAS) could be characterized as hierarchies of components interacting within and across scales with emergent properties that 
Table 4.2 Illustrations of where natural design principles could be translated into various types of innovations that support a sustainable, healthy, and just society

\begin{tabular}{|c|c|c|c|}
\hline Name & $\begin{array}{l}\text { Natural design } \\
\text { principle }\end{array}$ & Brief description & $\begin{array}{l}\text { Type of (potential) } \\
\text { innovation }\end{array}$ \\
\hline $\begin{array}{l}\text { Nature-based solutions } \\
\text { to climate change } \\
\text { adaptation }\end{array}$ & Resilience & $\begin{array}{l}\text { An approach that uses } \\
\text { biodiversity and } \\
\text { ecosystem services to } \\
\text { help people adapt to the } \\
\text { adverse effects of } \\
\text { climate change (Kabisch } \\
\text { et al. 2017) }\end{array}$ & $\begin{array}{l}\text { Climate change } \\
\text { adaptation in rural and } \\
\text { urban areas }\end{array}$ \\
\hline $\begin{array}{l}\text { Production of } \\
\text { mushrooms on local } \\
\text { residual flows }\end{array}$ & Circularity & $\begin{array}{l}\text { Companies grow } \\
\text { different kinds of } \\
\text { mushrooms based on } \\
\text { residual flows from other } \\
\text { companies, and sell the } \\
\text { mushrooms as a } \\
\text { valuable new product to } \\
\text { restaurants and others, } \\
\text { while the substrate can } \\
\text { be used for feed or other } \\
\text { purposes. }\end{array}$ & $\begin{array}{l}\text { Technological, } \\
\text { Organizational }\end{array}$ \\
\hline $\begin{array}{l}\text { Species richness helps } \\
\text { system respond to } \\
\text { disturbance }>\text { healthy } \\
\text { ecosystems } \\
\text { demonstrate } \\
\text { sustainability }\end{array}$ & $\begin{array}{l}\text { Resilience, } \\
\text { adaptive } \\
\text { capacity, } \\
\text { sustainability, } \\
\text { circularity }\end{array}$ & $\begin{array}{l}\text { Ecosystems survive } \\
\text { biotic and abiotic } \\
\text { disturbances by having } \\
\text { multiple species that } \\
\text { respond in different } \\
\text { ways (Main 1999; } \\
\text { Freudenstein et al. } \\
\text { 2017). Likewise, } \\
\text { diversity and life-span of } \\
\text { plants help prairie } \\
\text { ecosystems use water } \\
\text { and nutrients efficiently } \\
\text { (Glover et al. 2010) }\end{array}$ & $\begin{array}{l}\text { Ecological, social, } \\
\text { institutional }\end{array}$ \\
\hline Adaptive management & $\begin{array}{l}\text { Resilience and } \\
\text { adaptive } \\
\text { capacity }\end{array}$ & $\begin{array}{l}\text { Natural ecosystems } \\
\text { survive variable } \\
\text { conditions, disease } \\
\text { emergence, herbivores, } \\
\text { predators, and other } \\
\text { environmental changes } \\
\text { by having adaptive } \\
\text { responses (Tompkins } \\
\text { and Adger 2004) }\end{array}$ & $\begin{array}{l}\text { Institutional, social, } \\
\text { organizational, } \\
\text { community resilience, } \\
\text { and examples of } \\
\text { adaptive spatial } \\
\text { planning }\end{array}$ \\
\hline ManagemANT & $\begin{array}{l}\text { Behaviourial } \\
\text { strategies, self- } \\
\text { organization }\end{array}$ & $\begin{array}{l}\text { ManagemANT is a term } \\
\text { which combines the } \\
\text { words 'management' } \\
\text { and 'ant', and describes } \\
\text { the usage of behavioural } \\
\text { strategies of ants in } \\
\text { economic and } \\
\text { management strategies } \\
\text { (Fladerer and Kurzmann } \\
\text { 2019). }\end{array}$ & Social, economic \\
\hline
\end{tabular}


Table 4.2 (continued)

\begin{tabular}{|c|c|c|c|}
\hline Name & $\begin{array}{l}\text { Natural design } \\
\text { principle }\end{array}$ & Brief description & $\begin{array}{l}\text { Type of (potential) } \\
\text { innovation }\end{array}$ \\
\hline $\begin{array}{l}\text { Social networking aids } \\
\text { housing search }\end{array}$ & Networking & $\begin{array}{l}\text { Social networking } \\
\text { behaviours in hermit } \\
\text { crabs help them find new } \\
\text { homes through vacancy } \\
\text { chains (Rotjan et al. } \\
\text { 2010) }\end{array}$ & Social \\
\hline $\begin{array}{l}\text { Collaboration benefits } \\
\text { multiple participants }\end{array}$ & $\begin{array}{l}\text { Collaboration, } \\
\text { networking }\end{array}$ & $\begin{array}{l}\text { Several species of } \\
\text { epiphytes, ants, fungi, } \\
\text { and butterflies in } \\
\text { mangrove forests } \\
\text { provide benefits to each } \\
\text { other through mutualism } \\
\text { (Hogarth 2015). }\end{array}$ & Social, organizational \\
\hline $\begin{array}{l}\text { Community food } \\
\text { forestry/Community } \\
\text { agro-forestry }\end{array}$ & $\begin{array}{l}\text { Resilience, } \\
\text { circularity, } \\
\text { sustainability, } \\
\text { social } \\
\text { cohesion }\end{array}$ & $\begin{array}{l}\text { A food forest is a multi- } \\
\text { functional approach to } \\
\text { increase food security } \\
\text { and provide ecosystem } \\
\text { services (Clark and } \\
\text { Nicholas 2013). A well- } \\
\text { functioning food forest } \\
\text { is actually the most ideal } \\
\text { form of circular } \\
\text { agriculture, since a } \\
\text { healthy ecosystem } \\
\text { shows an important } \\
\text { basic principle of the } \\
\text { Circular Economy: that } \\
\text { is how you organize } \\
\text { circularity at the lowest } \\
\text { possible level. When } \\
\text { combining a food forest } \\
\text { with the concept of } \\
\text { community-supported } \\
\text { agriculture it provides } \\
\text { many opportunities for } \\
\text { social cohesion and } \\
\text { citizen participation to } \\
\text { restore the relationship } \\
\text { between citizens, food } \\
\text { production and nature. } \\
\text { Community Food } \\
\text { Forestry (CFF)/ } \\
\text { Community Agro- } \\
\text { Forestry (CAF) allows } \\
\text { citizens to become co- } \\
\text { owner of their own food } \\
\text { system. A first pilot is } \\
\text { being established by }\end{array}$ & $\begin{array}{l}\text { Ecologic, economic, } \\
\text { and social }\end{array}$ \\
\hline
\end{tabular}


Table 4.2 (continued)

\begin{tabular}{|c|c|c|c|}
\hline Name & $\begin{array}{l}\text { Natural design } \\
\text { principle }\end{array}$ & Brief description & $\begin{array}{l}\text { Type of (potential) } \\
\text { innovation }\end{array}$ \\
\hline & & $\begin{array}{l}\text { Inholland University in } \\
\text { the Netherlands. }\end{array}$ & \\
\hline $\begin{array}{l}\text { Collaborative } \\
\text { ecosystem/Creating } \\
\text { value in business } \\
\text { ecosystems }\end{array}$ & $\begin{array}{l}\text { Collaboration, } \\
\text { networking }\end{array}$ & $\begin{array}{l}\text { Breakthrough business } \\
\text { models can be created by } \\
\text { companies working } \\
\text { beyond the traditional } \\
\text { supply chain, and create } \\
\text { and scale system-level } \\
\text { impact by working with } \\
\text { non-traditional } \\
\text { partners-e.g. } \\
\text { competitors, other } \\
\text { industries and sectors } \\
\text { (e.g. Iansiti and Levien } \\
\text { 2004; Clarysse et al. } \\
\text { 2014). }\end{array}$ & Economic \\
\hline
\end{tabular}

cannot be predicted by knowing the components alone (Lansing 2003). As a consequence, 'an essential aspect of such systems is nonlinearity, leading to historical dependency and multiple possible outcomes of dynamics' (cf. Levin 1998).

Although complex adaptive systems can be hierarchical, they more often exhibit aspects of 'self-organization' (Holland 1995). Control is distributed rather than central (Allen and McGlade 1986; Pahl-Wostl 1995). Rather than trying to change the structure of complex, adaptive systems to make them controllable by external intervention, innovative management approaches aim at making use of the selforganizing properties of the systems to be managed. Ostrom (1990) convincingly shows that user communities of a common pool resource have the capacity for selforganization and self-governance and that there are many different viable combinations between the public and private sectors. Because the self-organizing properties of complex ecosystems and associated management systems seem to cause uncertainty to grow over time, understanding should be continuously updated and adjusted, and each management action viewed as an opportunity to further learn how to adapt to changing circumstances (Carpenter et al. 2001). The capacity to adapt to and shape change is an important component of resilience in a socialecological system (Olsson et al. 2004; Lebel et al. 2006; Berkes and Turner 2006). In short, complex adaptive systems are characterized by self-organization, adaptation, heterogeneity across scales, and distributed control.

The difficulty in analysing complex adaptive systems is the multitude of relevant variables and the interactions of said variables, which all affect the functioning of the systems on multiple levels. This complexity only increases when social systems and natural systems are interlinked, as is the case in water management, agriculture, forestry, fishery, spatial planning, and environmental quality. 
Our cities, for instance, are actually complex, adaptive, and multi-functional systems with a high degree of complexity and uncertainty. An important reason for this complexity is the dynamic interplay between a plethora of different systems in a single location. This goes for physical systems, such as buildings, streets, traffic systems, sewerage, gas, water, electricity, and communication networks, and the like, as well as non-physical systems, such as the job market, the economy, education, healthcare, politics and governance, law enforcement and, of course, the sociocultural system at the city, district and street level. This also means that many different actors are involved in governing and managing complex systems, each of which has their own values, interests, ambitions, and opinions about problems and solutions. In other words, there are many interrelated factors and actors that can influence the functioning and governance of our cities and rural areas. Uncertainty is a given that cannot be brushed aside or ignored but must be addressed if we are to organize and design an agile, resilient society. Examples of the uncertainties faced by society include climate change, economic developments, financial crises, political shifts, disasters, new technologies, and diverging views on problems, solutions, and impact.

The characteristic features of complex adaptive systems, such as a high degree of variety and uncertainty, has a high risk of failure for any attempt at direct planning (Verhees 2013). Steering and coordination of complex adaptive systems, therefore, requires adaptive governance or reflexive governance, the latter being defined by Voß and Kemp (2015: 8) as: 'the organization (modulation) of recursive feedback relations between distributed steering activities'. This strategic process requires five key elements (Voß and Kemp 2015: 17-20): (1) transdisciplinary knowledge production; (2) experiments and adaptive strategies and institutions; (3) anticipation of long-term effects of measures; (4) interactive participatory goal formulation; and (5) interactive strategy development. Governance approaches that are capable of dealing with complexity and uncertainty in complex adaptive systems are highlighted in the following Sect. 4.6.

Complex system sciences provide valuable insights into the possibilities for transition in a complex system, such as the water, food or energy system, and the sustainability transition more in general. An important insight is that the outcomes or symptoms (events) of a system are determined by underlying behavioural patterns and interactions, whereby those patterns are linked to systemic structures such as biophysical conditions, markets and legislation, which in turn are again determined by mental models or paradigms such as beliefs, traditions, or (cultural) values (Maani and Cavana 2007; see Fig. 4.3). In particular, the mental models, the bottom layer in Fig. 4.3, determine or maintain the structures and decision-making of a system. Many scholars argue that the sustainability transition requires a paradigm shift. A paradigm shift implies a change in mental models and core values, though I doubt whether this is truly necessary for a substantial part of the core values already present in our modern societies and constitutions, such as freedom, equality, justice, and solidarity. Nevertheless, it is clear that the divide between humans and nature that arose during the Enlightenment, and the capitalist economic logic and related economic structures that were put in place after the Second World War, have blurred 


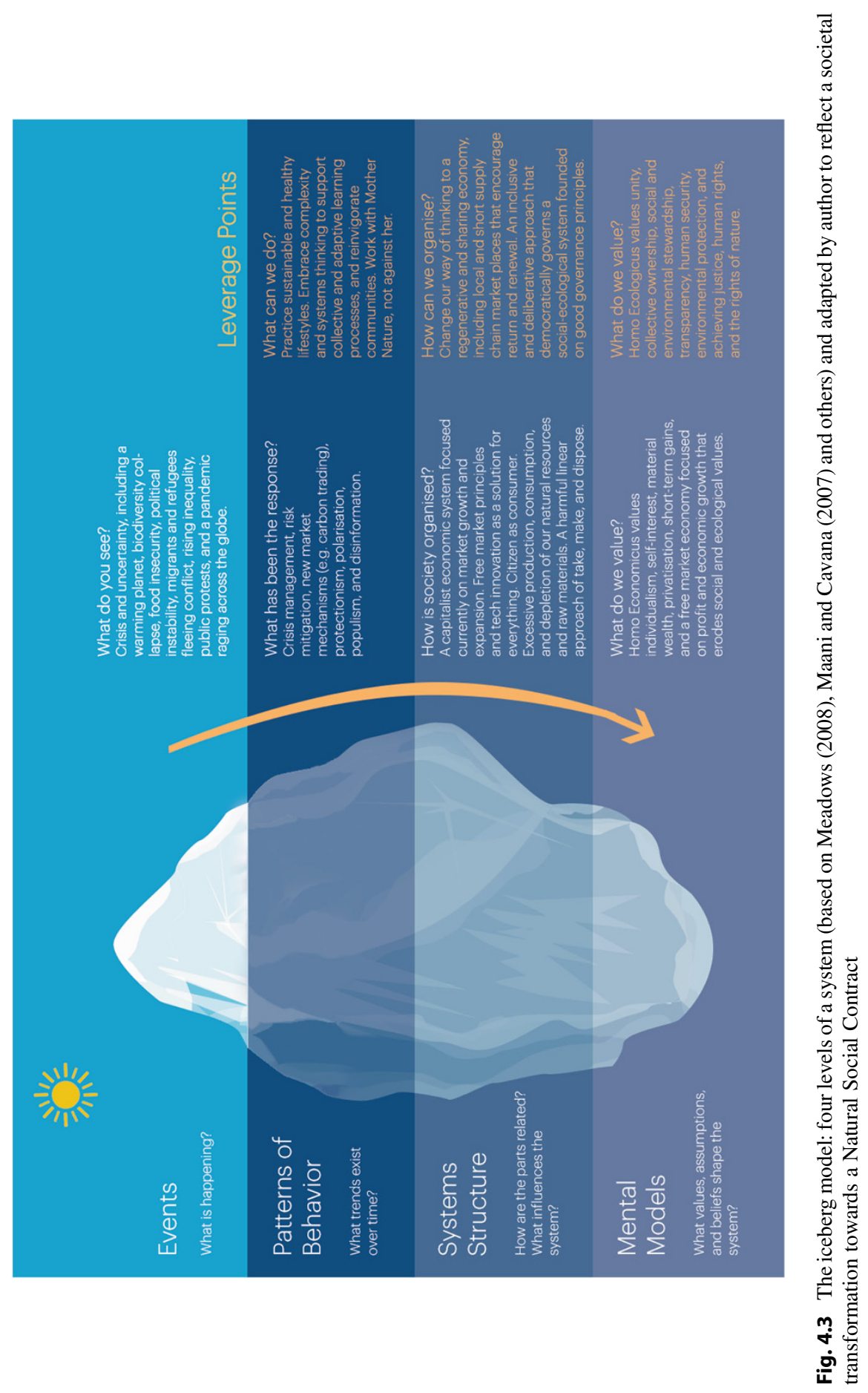


or ignored a number of important core values, such as social and environmental stewardship, planetary health, environmental security and justice, intergenerational justice and equity, and the Rights of Nature (see Sect. 3.8). Hence, it may be more important to resurrect the core values that are latent or have been blurred by current systemic structures. For example, during the Corona-pandemic we have witnessed a resurrection of solidarity, and a re-appreciation of people working in health care, food production, education, who were regarded as mere production factors in a neoliberal model and who had to hold up their hands for a decent salary before the Corona-crisis. They are now the heroes of society. Of course they already were, but appreciation for these professionals failed to materialize because it was overshadowed by the over-appreciation of the free market, market-based values, privatization, and unlimited economic growth. The point here is that current day values are also influenced by the systemic structures that we have put in place, due to a process of institutionalization, in which preferences are gradually strengthened until they are fixed and familiar (Parker et al. 2003). Hence, it is important to realize that the divide between humans and nature, as well as the capitalist economic logic, has gradually entered present day constitution, laws and legislation, as well as customary law, existing practices, norms and culture. However, there is little societal and scientific attention for the underlying patterns, structures, and paradigms that cause the symptoms (the events in Fig. 4.3) of systemic failures to recur over and over (IPBES 2019; Wallace et al. 2015). From this perspective, global warming, loss of biodiversity, and environmental degradation are merely symptoms of a deeper, systemic crisis, but because they are very visible they receive a lot of (political) attention.

An important question is where leverage points in a complex system can be found. These leverage points are places in a complex system where a small change could bring about major changes (Meadows 2008). As these leverage points focus on the deeper layers of the system, they increase in impact and are more transformative on the system (both positive and negative). Finding leverage points alone is not enough; system change also requires good insight into the interrelationships, for example, via (non-linear) feedback loops, and how the desired outcome can be achieved with maximum synergy effects and minimal 'trade-offs' (Kennedy et al. 2018). Adopting a systems-based approach helps recognize synergies and trade-offs, moving beyond linear, to more circular, inclusive systems' (cf. SAPEA 2020). 'Systems thinking is about seeing life in motion, recognizing that the big picture is rarely static, but almost always a web of factors that interact to create patterns and change over time' (Martella et al. 2019).

\subsection{Adaptive, Reflexive, and Deliberative Approaches to Governance}

The complexity and uncertainty of the problems we face today call for new forms of governance, management, and organization. In particular for sustainability development there is a broad and diverse field of governance studies that propose adaptive 
governance (e.g. Folke et al. 2005; Huitema et al. 2009; Termeer et al. 2010; Huntjens et al. 2011a, b; Ison et al. 2013; Chaffin et al. 2014), reflexive governance (e.g. Rip et al. 2006; Leach et al. 2007; Hendriks and Grin 2007; Voß and Bornemann 2011; Voß and Kemp 2015; Feindt and Weiland 2018), and deliberative governance as new pathways to sustainability. These concepts share a focus on addressing ambivalence, complexity, uncertainty, and distributed power in societal change. These governance concepts have been translated into various management approaches, of which transition management (as described in Sect. 4.2) and adaptive management (in this section) are two examples that evolved from the analysis of sociotechnical systems and social-ecological systems, respectively (Voß and Bornemann 2011).

The concept of adaptive management has been known for longer, especially within ecosystem management (Holling 1978; Walters 1986; Pahl-Wostl 1995; Lee 1999). An important starting point is that ecosystems are complex systems that are adaptive or self-organizing, and that management systems must, therefore, be able to respond to changes or surprises in the system (Gunderson and Holling 2002). The ability to adapt is an important part of resilience in a social-ecological system and is also called adaptive capacity (Berkes et al. 2002; Folke et al. 2005; Walker et al. 2004). Adaptive management is a systematic process to improve policy and practice by learning from the outcomes of previous activities and by taking into account changes in external factors, which is also known as a 'management as learning' approach (Gunderson et al. 1995).

The application of adaptive management has far-reaching consequences for policy and strategy development, and the translation of adaptive management into policy and strategy is what we call adaptive planning or adaptive governance. Adaptive planning requires strategies that can be adjusted in time (in the event of changing circumstances), space for experimentation and deliberation of alternative routes and measures (Huntjens et al. 2012). Ahern (2006) emphasizes that a transdisciplinary process, in which a certain level of uncertainty and risk is accepted, is necessary to achieve adaptive planning, which is why it is so important to activate a social learning process geared towards the process rather than a fixed goal (Bagheri and Hjorth 2007).

For example, there is a real risk that current climate and energy policies will be too rigid to achieve the policy objectives for carbon emission reduction. Because this policy is linked to an energy transition that is set to last several decades, it is inevitable that, a few years from now, we will find that a number of things turned out differently from how we thought they would. A more adaptive and robust policy should, on the one hand, provide investment security for businesses and, on the other hand, offer sufficient scope for adjustment in the light of new insights and political, economic, social, and technological developments. As things are now, for example, we cannot predict exactly which role hydrogen will play in the energy supply of the future, how quickly mobility will become electric, or how much progress will be made in the field of nuclear energy. Similarly, the consequences of new technologies such as artificial intelligence, quantum computers, blockchain technology, and big data are still unknown. It is, therefore, important to ensure that we do not develop 
climate and energy policies of such rigidity that they cannot be adjusted at a later stage.

In general, adaptive management and transition management provide a number of important insights for Transformative Social-Ecological Innovation, of which the importance of collective learning processes and social networks for coping with uncertainty and enabling change stands out. Collective learning processes (see Sect. 4.7) are required to develop the knowledge and ability to respond to new insights, with mechanisms that facilitate social learning, policy learning, and transformational learning (Huntjens et al. 2012; Beers et al. 2016). For instance, a transdisciplinary approach is required to enable collective learning (Sect. 4.10). Beyond interdisciplinary cooperation, a transdisciplinary cooperation between citizens, businesses, government, and other parties stimulates creativity, generates support for solutions, and allows for the production, exchange, and use of practical knowledge (see Sect. 4.10).

\subsection{Social Learning, Policy Learning, and Transformational Learning ${ }^{1}$}

Society's capacity to learn is perhaps the most essential property for realizing a societal transformation towards a Natural Social Contract. There is a large and diverse body of literature on various forms of collective learning, including literature on action learning, social learning, organizational learning, policy learning, and transformational learning. Action learning offers a widely accepted framework for understanding and engaging systematically in practical knowledge construction (Levy 2003). The concept of action learning is being applied in organizational learning (Argyris and Schön 1978, 1996), business management (Sterman 2000), financial sector, health sector (Levy 2003, on community empowerment; Hanks 2006, on community partnership), educational sector (Hwang 2000; Maurer et al. 2006), as well as in the agricultural sector, water management (2007; Huntjens et al. 2011a, b), and social innovation in sustainability transitions (Huntjens 2019). Social learning means learning together to solve a collective problem (Craps 2003; PahlWostl 2007). Social learning happens when people with different goals and resources successfully tackle a problem in which all have a stake (Craps 2003). Policy learning is an important concept in the field of public administration (Hall 1988; Bennett and Howlett 1992; Sanderson 2002; Kemp and Weehuizen 2005; Leicester 2007; Grin and Loeber 2007; Sabatier 1988; Sabatier and Jenkins-Smith 1993; van Buuren et al. 2016). Policy learning is defined as a 'deliberate attempt to adjust the goals or techniques of policy in the light of the consequences of past policy and new information so as to better attain the ultimate objects of governance' (Hall $1988,6)$. Policy learning involves a socially conditioned discursive or argumentative process of developing cognitive schemes or frames that question policy goals and

\footnotetext{
${ }^{1}$ Parts of this section are based on Huntjens (2011).
} 
assumptions (Sanderson 2002, 6). Transformational learning (also called triple loop learning) is a refinement of the original double loop learning concept by Argyris (1999), and helps to bring about fundamental shifts in thinking and attitude (Hargrove 2002:60). It starts with declaring powerful new possibilities for governance and management and then translating them into goals that take people and organizations beyond what they already think and know based on their own or organizational orthodoxies or experience (Hargrove 2002: 115), or to take them beyond their old management styles.

Lave and Wenger (1991) emphasize that a collective learning process cannot be divorced from the social context in which it takes place. At the core of this social theory of learning lies the concept of a community of practice (ibid.). This means that individuals learn by taking part in practice and gradually shift more to the core of the process, but the practice also participates in individuals by influencing thoughts and actions. This continuous change of perspective is particularly effective at highlighting the social dynamics and context of learning, with learning being considered a part of everyday life rather than a process that takes place solely in people's heads (ibid.).

An important hypothesis advanced in the literature is that cooperation with stakeholders, starting as early as possible in the process, promotes collective (or societal) learning (Boonstra 2004; Hisschemöller 2005; Muro and Jeffrey 2008; Stringer et al. 2006). It helps generate trust, develop a shared understanding of problems, solve conflicts and find shared solutions, ultimately enabling all stakeholders to achieve better results than they would have on their own (Craps 2003). Beers et al. (2016) address the relationship between social learning and transitions, empirically showing how the nature of the interaction relates to the outcomes and impacts of social learning.

Policy changes have been explained in terms of learning by Sabatier and JenkinsSmith (1999) through their Advocacy Coalition Framework (ACF). However, one limitation in the ACF is that advocacy coalitions take their identity from core beliefs, they are conservative of them and thus also of the policy positions they advocate (Weible et al. 2009). Conservatism leads Sabatier and Jenkins-Smith (1993) to propose that collective learning appears not from change within policy coalitions, but as a result of the changing influence of policy coalitions on the whole. In this model, the system learns without any learning on the part of policy coalitions or individuals. Movement is argued to be stimulated by shocks and trends exogenous to the system-including wider political change, legislative reform, or stressors such as climate change. By doing so, the ACF does not explicitly account for, or is ambiguous about, the role of ideas and self-interest in the policy process (e.g. Kübler 1999; Compston and Madsen 2001).

As Argyris and Schön (1996) have shown, changing values is far more difficult than changing practices. Argyris and Schön consider double loop learning more difficult than single loop learning, because it requires changes to values. Individuals tend to avoid challenging established values. Argyris and Schön (1996) argue this is for three reasons: 


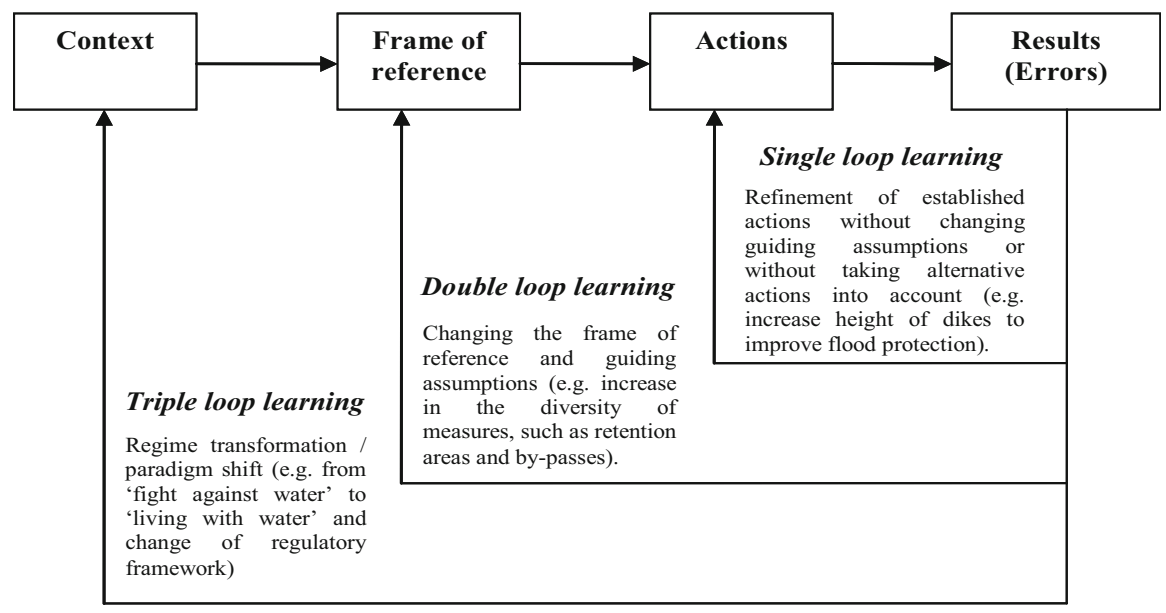

Fig. 4.4 Triple loop learning concept derived from Hargrove (2002), and adjusted by Huntjens et al. $(2011 \mathrm{a}, \mathrm{b})$

- Individual risk aversion that leads actors to avoid direct interpersonal confrontations and public discussion of sensitive issues which might expose the actor to future negative repercussions.

- A desire to protect others by avoiding the testing of assumptions where this might evoke negative feelings and by keeping others from exposure to blame.

- A wish to control the situation by keeping your own view private and avoiding any public questioning which might refute it.

It is important to recognize that policies change in a variety of different ways. As has long been recognized, some policies are new and innovative, while others are merely incremental refinements of earlier policies (Hogwood and Peters 1983; Polsby 1984). In other words, policy learning may have different levels of intensity (Pahl-Wostl et al. 2007). Some scholars have conceptualized societal transformation as social and societal learning that proceeds in a stepwise fashion moving from single to double to triple loop learning (Pahl-Wostl 2009; Huntjens et al. 2011a, b), making use of the concept of double loop learning (Argyris 1999) and triple loop learning (Hargrove 2002), as an extension of the double loop concept (see Fig. 4.4).

Section 5.3 provides an operationalization and framework for analysing different levels of collective learning in societal transformation. Section 5.4 will provide more detail on collaborative action research, and related methods to stimulate and facilitate interaction, participation, social learning, and co-creation. 


\subsection{Shared Value, Multiple Value Creation, and Mutual Gains}

For studying Transformative Social-Ecological Innovation (TSEI) it is necessary to pay attention to the incentives, thinking, and actions of the actors involved and the conditions that influence this. Special attention is paid to the values that the actors use and the way in which they are expressed in the cooperation. There are various approaches that provide useful insights, such as shared value creation (Porter and Kramer 2002, 2019), integrated value creation (Visser and Kymal 2015), mutual gains approach (Susskind and Field 1996; Susskind and Cruikshank 2006; Rodríguez-Carvajal et al. 2010; Ryan and Wallace 2019), multiple value creation, and co-creation (see Sect. 4.8). In this section I will briefly highlight some key insights from this literature.

Porter and Kramer (2002, 2019), Porter et al. (2012) introduced the concept of Creating Shared Value (CSV), which is closely related to the concept of Corporate Social Responsibility (CSR) (De Witte and Jonker 2006). Porter and Kramer make a strong plea for a fundamental revision of capitalism, although still very much relying on market mechanisms, profit making (although broader defined), and the 'competitive context' of society. Their argument is that by serving social and ecological interests, companies will earn money. After all, companies are focused on innovation and with that they excel the change towards a better society. According to Porter and Kramer, capitalism remains the best and most efficient way to create value, but traditional capitalism sees only 'profit' as value. The government and other powers should try to ensure that this pursuit of profit does not lead to serious abuses. The new capitalism of Porter and Kramer pays much more attention to the common interest and creates value based on social interest and not only on the interest of the shareholders. Society has an enormous amount of needs that are not or insufficiently met. Think, for example, of solving issues in the field of the environment, health care, the scarcity of raw materials, education, and employment.

According to Porter et al. (2012), companies can create shared value opportunities in three ways:

1. Reconceive products and markets to provide appropriate services and meet unmet needs.

2. Redefine productivity in the value chain to mitigate risks and boost productivity.

3. Enable local cluster development by improving the external framework that supports the company's operations, for example, by developing the skills of suppliers.

Moon et al. (2011) added one more step to define core competence, while also incorporating internationalization, an aspect that was missing in Porter \& Kramer's work:

4. Enabling local or global cluster development (Moon et al. 2011). 


\begin{tabular}{|c|c|c|}
\hline LEVELS OF SHARED VALUE & BUSINESS RESULTS & SOCIAL RESULTS \\
\hline $\begin{array}{l}\text { Reconceiving product } \\
\text { and markets: }\end{array}$ & $\begin{array}{l}\text { - Increased revenue } \\
\text { - Increased market share }\end{array}$ & $\begin{array}{l}\text { - Improved patient care } \\
\text { - Reduced carbon footprint }\end{array}$ \\
\hline $\begin{array}{l}\text { How targeting unmet needs drives } \\
\text { incremental revenue and profits }\end{array}$ & $\begin{array}{l}\text { - Increased market growth } \\
\text { - Improved profitability }\end{array}$ & $\begin{array}{l}\text { - Improved nutrition } \\
\text { - Improved education }\end{array}$ \\
\hline $\begin{array}{l}\text { Redefining productivity } \\
\text { in the value chain: } \\
\text { How better management of } \\
\text { internal operations increases } \\
\text { productivity and reduces risks }\end{array}$ & $\begin{array}{l}\text { - Improved productivity } \\
\text { - Reduced logistical and } \\
\text { operating costs } \\
\text { - Secured supply } \\
\text { - Improved quality } \\
\text { - Improved profitability }\end{array}$ & $\begin{array}{l}\text { - Reduced energy use } \\
\text { - Reduced water use } \\
\text { - Reduced raw materials } \\
\text { - Improved job skills } \\
\text { - Improved employee incomes }\end{array}$ \\
\hline Enabling cluster development: & - Reduced costs & - Improved education \\
\hline $\begin{array}{l}\text { How changing societal conditions } \\
\text { outside the company unleashes } \\
\text { new growth and productivity gains }\end{array}$ & $\begin{array}{l}\text { - Secured supply } \\
\text { - Improved distribution } \\
\text { infrastructure } \\
\text { - Improved workforce access } \\
\text { - Improved profitability }\end{array}$ & $\begin{array}{l}\text { - Increased job creation } \\
\text { - Improved health } \\
\text { - Improved incomes }\end{array}$ \\
\hline
\end{tabular}

Fig. 4.5 Levels of shared value creation and types of value created in each area (Porter et al. 2012)

Porter et al. (2012) provide further examples of the types of value created in each area (see Fig. 4.5).

A critical study on shared value creation by Pirson (2012) found that 'innovative shared value creating ventures opted out of balance-oriented, shared value creation strategies and embraced either financial or social-value primacy strategies over time. The findings thus question the power of the shared value creation notion when viewed as balance orientation' (cf. Pirson 2012). A common criticism of CSV is the downplay of trade-offs that businesses have to make (The Economist 2011). Furthermore, a literature review on shared value creation by Williams and Hayes (2013) shows there is little documentation of its influence elsewhere, with exception of some examples, with varying degrees of success, of US-based multinationals. 'There has been little rigorous analysis into the impact of CSV mechanisms, with the majority of evidence existing as standalone case studies of mixed analytical rigour' (cf. Williams and Hayes 2013). London (2009) furthermore argues that the predominant focus in terms of social impact is on income, missing wider social-ecological dimensions. 'All current measurement models suffer from standard impact challenges, with the emphasis on tasks completed or products distributed rather than outcomes' (cf. Williams and Hayes 2013).

In addition to shared value thinking there is literature on the concept of integrated value creation (IVC), which resembles shared value creation, but is not exactly the same (Visser and Kymal (2015). Practically, 'IVC helps a company integrate its response to stakeholder expectations (using materiality analysis) through its management systems (using best governance practices) and value chain linkages (using life cycle thinking)' (cf. Visser and Kymal 2015). Visser (2017) provides the following working definition of IVC: "integrated value is the simultaneous building 
of multiple 'non-financial' capitals (notably infrastructural, technological, social, ecological, and human capital) through synergistic innovation across the nexus economy (including the resilience, exponential, access, circular, and well-being economies) that result in net-positive effects, thus making our world more secure, smart, shared, sustainable, and satisfying".

Originating from political sciences, and negotiation theory more in particular, the mutual gains approach (MGA) offers valuable insights for complex multi-party problem solving. It has been successfully used in many negotiations, mainly related to trade, labour, and environmental negotiations (Susskind and Field 1996; Kirk et al. 2008; Rodríguez-Carvajal et al. 2010; Ryan and Wallace 2019), while also applied in citizen engagement, process facilitation, mediation, and conflict resolution, for instance, to mediate in the Israeli-Palestinian water conflict (Huntjens 2017).

The mutual gains approach is highly valuable in situations where two or more people are negotiating to reach an agreement that may be of benefit to both or all of them (Consensus Building Institute 2014). The MGA-approach lays out four steps for negotiating better outcomes while protecting relationships and reputation. The 4 phases of the mutual gains process include (cf. CBI 2014):

1. Preparation: Prepare by understanding interests and alternatives. More specifically, estimate your BATNA and how other parties see theirs (BATNA stands for 'best alternative to a negotiated agreement'). Having a good alternative to agreement increases your power at the table (Raiffa 1982; Fisher et al. 1991; Zartman and Rubin 2000).

2. Creating Value: Create value by inventing without committing. A central feature of the mutual gains approach is a focus on interests, not positions. Based on the interests uncovered or shared, parties should declare a period of 'inventing without committing' during which they advance options by asking 'what if. ..?' By doing so, parties can discover additional interests, create options that had not previously been imagined, and generate opportunities for joint gain by trading across issues they value differently (Fisher et al. 1991; Bazerman and Neal 1992).

3. Distributing Value: At some point in a negotiation, parties have to decide on a final agreement. This is easier to do when there is trust between the parties, and the more value they have created, the easier this will be (Fisher et al. 1991), but research suggests that parties default very easily into positional bargaining when they try to finalize details of agreements (Mnookin et al. 2000). Parties should divide value by finding objective criteria that all parties can use to justify their 'fair share' of the value created. By identifying criteria or principles that support or guide difficult allocation decisions, parties at the negotiating table can help the groups or organizations they represent to understand why the final package is not only supportable, but fundamentally 'fair'. This improves the stability of agreements, increases the chances of effective implementation, and protects relationships.

4. Implementation and follow-up: Follow through by imagining future challenges and their solutions. Parties near the end of difficult negotiations—or those who 
will 'hand off' the agreement to others for implementation-often forget to strengthen the agreement by imagining the kinds of things that could derail it or produce future conflicts or uncertainty (Bazerman and Watkins 2004; Susskind and Cruikshank 2006). While it is difficult to focus on potential future challenges, it is wise to include specific provisions in the final document that focus on monitoring the status of commitments; communicating regularly; resolving conflicts or confusions that arise; aligning incentives and resources with the commitments required; and helping other parties who may become a de facto part of implementing the agreement (Lax and Sebenius 2006). Including these provisions makes the agreement more robust and greatly assists the parties who will have to live with it and by it (Susskind and Cruikshank 2006).

In the search for mutual gains, participants are encouraged to explore more ways to create more value (i.e. to increase the pie) and generate a broader vision on sharing benefits. To illustrate, whenever action is taken to remedy environmental problems, the benefits also cascade: for instance, nurturing wildlife and flora in a wetland can also reduce water pollution and soil erosion, and protect crops against storm damage, alleviating water scarcity and allowing for more food production. In other words, working on one aspect of human security (i.e. environmental security in above example) may contribute to other aspects of human security (i.e. water and food security in above example). During mediation in the Israeli-Palestinian water conflict this aspect of multiple value creation was demonstrated by a multifunctional usage approach, in which the same cubic metre of water is being used by multiple users at different points in time before it flows into the river, among other thanks to centralized or distributed waste water treatment and recycling (Huntjens 2017). A central tenet of the MGA-approach is that a vast majority of negotiations in the real world involve parties who have more than one goal or concern in mind and more than one issue that can be addressed in the agreement they reach. The MGA-approach allows parties to improve their chances of creating an agreement superior to existing alternatives.

\subsection{Effective Cooperation}

There is currently no academic consensus on the definition of 'effective cooperation', with some authors suggesting that cooperation is effective if it leads to mutual satisfaction between the parties involved (Grey et al. 2009, p. 19). However, mutual satisfaction need not necessarily coincide with effective cooperation, as satisfaction is a state of mind whereas effective cooperation often boils down to a combination of economic profits and political gains. Huntjens et al. (2016), therefore, state that cooperation can only be considered effective if, on the one hand, there is sufficient trust between stakeholders with different or even conflicting interests, in order to reach a mutually accepted agreement and, on the other hand, when the intended results of the agreement are achieved. Effective cooperation can, therefore, be defined as 'cooperation in which two or more parties come to a negotiated 
compromise on maximizing mutual benefits and achieving shared gains for the parties involved' (cf. Grey et al. 2010, p. 158).

Maximizing mutual benefits, however, is only one of the factors that contribute to mutual satisfaction. For example, focusing on effectiveness can turn out for the worse (for examples, see New Public Management, Dunleavy et al. 2006) if results become more important than the process by which they are achieved. As such, procedural justice and psychological satisfaction are two other important elements that lead to mutual satisfaction for all parties involved (Creighton et al. 1998, p. 55; Lawrence et al. 1997).

In order for cooperation to be effective, it is important that the cooperating and decision-making process is conducted in a fair and equitable manner (see the literature about procedural justice and distributive justice). The solution is often to bring stakeholders together at an early stage, so that they can all contribute their ideas to the process, cooperate, and take part in decisions. This ensures that solutions enjoy more support and are better adapted to their social context, boosting their effectiveness.

It goes without saying that simply reaching an agreement is not enough: the intended results must also be achieved. If the parties involved fail to achieve what they set out to do, the process cannot be considered effective cooperation and stakeholders will be dissatisfied. Achieving the intended results is also called the level of compliance, which is used as a measure of institutional effectiveness (Biermann et al. 2007, p. 10).

Multi-party cooperation is paramount for issues and developments:

- that matter to multiple stakeholders.

- that involve various stakeholders who depend on each other to achieve their goals.

- that are characterized by incomplete or distributed knowledge.

- where there is little consensus about the problems at hand or the solutions to these problems.

Table 4.3 provides an overview of perceived advantages and disadvantages of cooperation.

\subsection{Transdisciplinary Approach, Living Labs, and Citizen Science}

The sustainability transition requires new forms of cooperation, organization, and governance, which calls for the commitment and creativity of many different people who work and live in the district, city, or region in question, as well as people working on urban and regional development. This, in turn, will necessitate more parties, such as real estate parties, project developers, municipalities, provinces and ministries, water boards, SMEs, farmer cooperatives, citizens, and NGO's, as well as scientists from different disciplines to start working together. 
Table 4.3 Perceived advantages and disadvantages of cooperation

\begin{tabular}{|c|c|}
\hline Possible advantages of cooperation & Possible disadvantages of cooperation \\
\hline $\begin{array}{l}\text { - win-win solutions as a result of } \\
\text { broadening the scope, } \\
\text { - new knowledge through social learning, } \\
\text { - locally adapted solutions, } \\
\text { - more support for solutions, } \\
\text { - prevention of claims and litigation, } \\
\text { - improved communication and } \\
\text { cooperation between people and } \\
\text { organizations, } \\
\text { - mutual trust between people, } \\
\text { organizations, and authorities, } \\
\text { - improved social cohesion, } \\
\text { - shared ownership and buy-in, } \\
\text { - scope for different needs and interests, } \\
\text { - improved funding opportunities, }\end{array}$ & $\begin{array}{l}\text { - time-consuming, } \\
\text { - decisions tend to be compromises, } \\
\text { disappointment because of unrealistic } \\
\text { expectations, } \\
\text { - project process can be chaotic and difficult to plan } \\
\text { and predict, } \\
\text { - solutions that may not technically be the best } \\
\text { solutions to the problem, } \\
\text { - (partial) loss of control } \\
\text { - process management/facilitator (rather than only } \\
\text { project implementation), } \\
\text { - higher costs (e.g. for extra facilities, travel } \\
\text { expenses for participants and professional } \\
\text { facilitators), } \\
\text { - liability/risk for not involving the right or all } \\
\text { stakeholders, or the process is perceived as biased } \\
\text { by certain shareholders. }\end{array}$ \\
\hline
\end{tabular}

Combining knowledge from different disciplines is known as multidisciplinarity, while cross-field cooperation between academic disciplines is termed interdisciplinarity. However, solely integrating knowledge from different fields is not enough to tackle complex societal issues. Rather, this must be combined with a participatory approach, resulting in what is called transdisciplinarity (Van Buuren en Edelenbos 2004; Reed 2008; Pahl-Wostl 2007). Transdisciplinary research involves interdisciplinary academic cooperation in collaboration with societal actors who do not necessarily have an academic background, with the aim of developing knowledge that is relevant for practice.

In particular, there is a need for such a transdisciplinary approach when there is incomplete knowledge about an issue, when knowledge is distributed among multiple stakeholders, and when there is little consensus about the problems at hand or the solutions to these problems. By definition, TSEI processes are marked by a high degree of complexity and uncertainty, as they often involve a multitude of interrelated factors and actors. As such, there is more to such processes than technological innovations and interventions alone, and social, cultural, economic, and administrative aspects also play a role, as does the process of multi-party cooperation.

In this respect, it is important not only to facilitate interdisciplinary cooperation but also, and above all, to involve citizens, entrepreneurs, governments, and other practically relevant parties (transdisciplinarity). By doing so, it becomes possible to produce, exchange, and use practically relevant knowledge. A transdisciplinary approach is needed to mobilize system knowledge, promote creativity, and generate support for new solutions (see also Wicked Philosophy by Coyan Tromp 2018).

In practice, a transdisciplinary approach for addressing sustainability issues has found its way in various countries in the form of living labs, which on itself could be considered a societal innovation. Living labs are physical locations where 
fundamental, applied and practice-oriented researchers, citizens, businesses, and government agencies work together to solve societal problems in a lifelike setting. A living lab is an open innovation ecosystem in which products or services are developed, tested, and used together with the people, businesses, or organizations who will actually use them. This real-life environment is essential for the development of innovative solutions that can survive the complexity of real life and daily practice (Maas et al. 2017). Often, organizational and/or societal innovations turn out to be decisive (ibid.). The setting of a living lab allows participants to study various aspects of physical and social systems and the relationships between such systems, focusing in particular on human interaction with systems and cooperation between stakeholders. This makes living labs a valuable component of the research methodologies adopted by this research group.

Within the broad field of transdisciplinary approaches, citizen science is becoming increasingly popular. Citizen science is sometimes described as 'public participation in scientific research', and often referred to in relation to participatory monitoring and participatory action research (Irwin 1995; Hand 2010; Bonney et al. 2014; Doyle et al. 2019). For example, citizen science is actively used for biodiversity monitoring (Theobald et al. 2015; Chandler et al. 2017), for monitoring of (micro)plastics and their associated pollution (Turns 2019), for crop variety selection for climate adaptation, involving thousands of farmers (Van Etten et al. 2019), and more recently, also for monitoring the spread of the Coronavirus (Covid19) pandemic. As such, citizen science provides an important avenue for the co-creation of actionable knowledge and solutions (Santha 2020). In particular, Internet and smartphones have increased the options for citizen science. Section 5.4 provides more detail on action research, and collaborative action research in particular, which refers to the involvement of practitioners and stakeholders in practice-driven research, instead of only citizens and scientists, which is usually the case in citizen science.

\subsection{The Art of Co-creation: Approaches, Principles, and Pitfalls}

At its core, Transformative Social-Ecological Innovation (TSEI) requires a process of co-creation tailormade to purpose and context, in which different parties work together to solve a complex societal problem or challenge. But co-creation does not happen automatically, and requires a well-considered approach depending on many factors and accounts for complexity and uncertainty. In practice, numerous multistakeholder workshops and dialogues, design sessions, round table discussions, and brainstorming sessions along with hackathons, living labs, urban labs, and field labs have become popular ideation settings. And yet, it remains understudied how the co-creation of knowledge and practices develop and flourish within such multi-actor learning environments (Puerari et al. 2018). Most studies focus on the identification of influential factors, while hardly any attention is paid to the outcomes (Voorberg et al. 2015). Effectiveness of co-creation trajectories clearly depends not just on the quality of participation and facilitation, as is widely acknowledged, but also on the 
preparation of conveners and the follow-up actions of participants around main events (Huntjens et al. 2017). This raises an important question as to what extent the right method or approach has been chosen to actually realize co-creation, social learning, effective cooperation, and mutual trust. For every phase and aspect of a co-creation trajectory there exists a wide choice of approaches (see Table 4.4 below) and methods (see examples in Sect. 4.7) available to convene parties, inspire collective problem solving, achieve consensus or at least consent, and encourage effective implementation. In this section, therefore, I give an overview of different approaches from which I will distill some basic principles and pitfalls for co-creation.

Table 4.4 provides an illustrative overview (non-exhaustive and in no particular order) of the various approaches available for co-creation. Differences between these approaches depend on the context in which they are applied. For example, focus and purpose (e.g. open innovation, new business model, or systemic innovation), level of complexity in the area of application, methodology (including time and resources required), and the level of education and competences of participants and facilitators. Hence, choosing the most suitable approach determines the success of co-creation in terms of effectiveness, efficiency, and fairness (i.e. procedural justice). This requires considering several additional factors, such as:

- Nature of the problem or the challenge (e.g. field of application, level of complexity, shared sense of urgency, degree of diversity (or conflict) in interests and perspectives, expected outputs, outcomes, impacts, etc.)

- Intended goal or purpose of the co-creation process (e.g. product, service, agreement, plan, strategy, tactics, learning goals, etc.)

- Time and resources available.

- Competences of participants and facilitators regarding methodology, process, and content. This also includes openness to dialogue, and willingness to be explicit about one's underlying assumptions and mental models, etc.).

- Commitment and ownership of contributors/problem owners, in particular to what extent (intended) participants are willing to cooperate, contribute, share knowledge, and follow-up and implement the agreed upon actions or results of the co-creation trajectory. The latter relates to strategic knowledge management and how intellectual property rights (IPRs) can facilitate the sharing of technology and of know-how, thus supporting collaborative innovation.

- Safe environment for open dialogue and exchange (e.g. Chatham House Rules).

- Path dependence (history, possible tensions/conflicts, social relationships between participants, phase in planning or policy cycle, etc.)

- Ethical issues, for example, equal access to information generated by the process for all participants, a process that maximizes the opportunities for involvement of all participants (i.e. procedural justice), or responsibility for maintaining confidentiality (e.g. in case of Chatham House rules).

When a company or organization uses an open innovation model it recognizes that knowledge from multiple external sources is necessary to enhance innovation 
Table 4.4 Overview of different approaches for co-creation (non-exhaustive and in no particular order)

\begin{tabular}{|c|c|c|}
\hline Approach & Focus & Context \\
\hline Open innovation model & Business model & $\begin{array}{l}\text { Open innovation model is the } \\
\text { mainstream model used for (mostly) } \\
\text { technological innovations in open } \\
\text { market economy (supply-side } \\
\text { driven) (e.g. Chesbrough 2006; Lee } \\
\text { et al. 2010; Gassmann et al. 2010) }\end{array}$ \\
\hline Boundary work & $\begin{array}{l}\text { Business model } \\
\text { innovation for } \\
\text { sustainability }\end{array}$ & $\begin{array}{l}\text { Multiple value creation via cross- } \\
\text { sector collaboration, which requires } \\
\text { changes in the boundaries of } \\
\text { identity, power, competence, and } \\
\text { efficiency (e.g. Zietsma and } \\
\text { Lawrence 2010; Clark et al. 2016; } \\
\text { Velter et al. 2020) }\end{array}$ \\
\hline Design thinking & User-centred & $\begin{array}{l}\text { Open market economy (demand- } \\
\text { side driven) (e.g. Rowe 1987; } \\
\text { Brown 2008; Dorst 2011; Black } \\
\text { et al. 2019) }\end{array}$ \\
\hline $\begin{array}{l}\text { Shared value creation } \\
\text { (SVC) /integrated value } \\
\text { creation (IVC) }\end{array}$ & $\begin{array}{l}\text { Business model/multiple } \\
\text { value creation }\end{array}$ & $\begin{array}{l}\text { Open market economy (SVC: Porter } \\
\text { and Kramer 2002, 2019; IVC: Visser } \\
\text { and Kymal 2015) }\end{array}$ \\
\hline $\begin{array}{l}\text { Mutual gains approach } \\
\text { (MGA) }\end{array}$ & $\begin{array}{l}\text { Conflict resolution/ } \\
\text { multiple value creation / } \\
\text { stakeholder management }\end{array}$ & $\begin{array}{l}\text { Negotiation, mediation, and value } \\
\text { creation in multiple stakeholder } \\
\text { settings (e.g. international trade or } \\
\text { environmental negotiations) } \\
\text { (e.g. Susskind and Field 1996; } \\
\text { Susskind and Cruikshank 2006; } \\
\text { Rodríguez-Carvajal et al. 2010; } \\
\text { Huntjens 2017; Ryan and Wallace } \\
\text { 2019) }\end{array}$ \\
\hline $\begin{array}{l}\text { Reflexive interactive } \\
\text { design (RIO-approach) }\end{array}$ & Systemic innovation & $\begin{array}{l}\text { Transition management (e.g. Bos } \\
\text { et al. 2009; Bos and Grin 2012; } \\
\text { Bremmer and Bos 2017; Puente- } \\
\text { Rodríguez et al. 2019) }\end{array}$ \\
\hline $\begin{array}{l}\text { Strategic niche } \\
\text { management }(\mathrm{SNM}) / \\
\text { transition experiments }\end{array}$ & Systemic innovation & $\begin{array}{l}\text { Transition management (e.g. Kemp } \\
\text { et al. 1998; Schot and Geels 2008; } \\
\text { Raven et al. 2010; Witkamp et al. } \\
\text { 2011; Luederitz et al. 2017) }\end{array}$ \\
\hline $\begin{array}{l}\text { Collaborative action } \\
\text { research (CAR)/ } \\
\text { Participatory action } \\
\text { research (PAR) }\end{array}$ & $\begin{array}{l}\text { Participatory knowledge } \\
\text { development/ } \\
\text { transdisciplinary } \\
\text { collaboration }\end{array}$ & $\begin{array}{l}\text { Wicked problems (e.g. Eden and } \\
\text { Huxham 1996; Checkland and } \\
\text { Holwell 1998; Baum et al. 2006; } \\
\text { Reason and Bradbury 2005; } \\
\text { Huntjens et al. 2011b, 2014a, b, c) }\end{array}$ \\
\hline
\end{tabular}

${ }^{a}$ Efficiency refers to the (perceived) efficient locus of transaction governance (Santos and Eisenhardt 2005) 
and deliver additional value for customers or clients. This sits in contrast to closed innovation in which a company strives to generate the best ideas entirely on its own. Although the open innovation model purposefully uses the inflows and outflows of knowledge to accelerate innovation (Chesbrough 2006), it is by definition an internally oriented process with a prime focus on maximizing utility and market expansion to the benefit of the company itself. Other approaches, such as shared value creation (SVC) and integrated value creation (IVC) stress the common interest with the purpose to create value based on social and ecological interests and not only on the interest of the shareholders (see Sect. 4.8).

SVC and IVC approaches argue that by serving social and ecological interests, companies will earn money. As such these approaches rely heavily on market mechanisms, profit making (although broader defined), and the 'competitive context' of society, and, therefore, tailored to an open market economy. Other approaches, such as the mutual gains approach (MGA) or those more related to transition management (e.g. RIO and SNM), focus explicitly on solving complex or wicked societal problems or challenges as something that requires changes in dominant structures (regimes). This is particularly true where multiple parties recognize mutual dependency and the importance of finding common ground and values in order to arrive at collective problem solving, systemic innovation, and joint implementation. These approaches have been explicitly developed to better deal with complexity and uncertainties with specific attention for issues of politics and power and drawing on the wider field of governance and innovation studies as well as other fields like complexity theory and systems theory.

Despite these differences in approaches to co-creation there remain many common denominators in the process of co-creation. Based on a literature review (e.g. Voorberg et al. 2015; Huntjens et al. 2017; Puerari et al. 2018) and drawing from years of practical experience in many co-creation trajectories-either as convener, mediator, organizer, or participant-I have identified a number of basic principles and common pitfalls of co-creation (Table 4.5). 
Table 4.5 Principles and pitfalls of co-creation

\begin{tabular}{l} 
Principle of co-creation \\
\hline Focus on collective problem
\end{tabular}
solving
Explanation and potential pitfalls

Co-creation involves collective problem solving with multiple parties, and where multiple parties recognize mutual dependency and the importance of finding common ground, shared values, and mutually accepted solutions. Dominance of one-sided interests or power, hidden agendas, lack of trust, incomplete configuration of problem owners and knowledge providers, and biased or incomplete information are common pitfalls. Likewise, a lack of commitment, ownership, and enthusiasm are common obstacles to co-creation, often due to an absence of attractive value propositions for all.

\begin{tabular}{|l|l}
\hline Safe environment & A safe environment for open, empathetic, and equal dialogue,
\end{tabular} and open exchange of information and reciprocity (e.g. through Chatham House rules) are important requirements for co-creation. It is supported by equality and trust among participants. e.g. by using a Round Robin approach where every participant has an equal voice and opportunity to co-create. Power imbalances and mistrust between participants may feed feelings of insecurity and exacerbate an unwillingness to co-create. In this vein, insufficient insights into complex social relationships and history between participants risks creating a weak environment for exchange and reciprocity.

Skilled and neutral facilitation

Co-creation requires a structured, safe, and creative process under the guidance of a skilled and neutral process manager, facilitator, or coach. Complex trajectories of co-creation usually involve more people in various roles to organize and facilitate the process. An important factor is the right choice of approach and methods, whereas more advanced approaches or methods (e.g. for one step or phase in the co-creation process) may require ample experience and skills. Also, the neutrality of the facilitator needs to be accepted by all parties and requires mediation skills in case of conflicting parties.

Delicate interplay between process and content
Co-creation relies on a well-informed and comprehensive understanding of the collective problem, problem owners, different interests and perspectives, and possible solutions which can be achieved by open, shared, and multiple information sources that fill knowledge gaps and facilitate integration. At the same time, it needs to be recognized that many uncertainties cannot be resolved. A multi-disciplinary advisory board could help to overcome knowledge gaps and other barriers to creativity. Too much emphasis on action and results could lead to a lack of reflection, superficial treatment of problems, and a lack of scientific support. Vice versa, too much emphasis on a science-proof co-creation process could serve as a limitation for creativity and out-of-the-box thinking.

Depending on the subject and the different parties, expertise, and disciplines involved in the process, communication and language problems regularly occur. The use of unfamiliar terminology without providing adequate definition is a common pitfall. Finding a common language, transparency, 
Table 4.5 (continued)

\begin{tabular}{|c|c|}
\hline Principle of co-creation & Explanation and potential pitfalls \\
\hline & $\begin{array}{l}\text { and clear communication are, therefore, important factors in } \\
\text { the co-creation process. Continuous reflection on behaviour } \\
\text { and use of language and its effects on the process only becomes } \\
\text { possible in a cooperative environment with intense and } \\
\text { informal interaction. }\end{array}$ \\
\hline $\begin{array}{l}\text { Finding attractive value } \\
\text { propositions for all }\end{array}$ & $\begin{array}{l}\text { The challenge for co-creation is to find attractive value } \\
\text { propositions for all who are involved. This requires design } \\
\text { thinking and valuation activities. Valuation can be done } \\
\text { through quantitative methods and through the use of words } \\
\text { (e.g. sustainable, animal well-being, benefits for the local } \\
\text { community) }\end{array}$ \\
\hline $\begin{array}{l}\text { Fair distribution of costs and } \\
\text { benefits }\end{array}$ & $\begin{array}{l}\text { The distribution of costs and benefits should be viewed as fair. } \\
\text { This applies to the process and content of co-creation, but also } \\
\text { to the outputs, outcomes, and impacts of co-creation. This } \\
\text { requires the involvement and strong representation of groups } \\
\text { and stakeholders who will be affected or are particularly } \\
\text { vulnerable. Stakeholder involvement and 'buy-in', or } \\
\text { ownership, is crucial for identifying acceptable trade-offs, for } \\
\text { negotiating distributions of costs and benefits and for reaching } \\
\text { consensus about the proposed solutions. }\end{array}$ \\
\hline $\begin{array}{l}\text { Balance between common } \\
\text { ground and diversity }\end{array}$ & $\begin{array}{l}\text { Diversity in knowledge, perspectives, and interests supports } \\
\text { idea generation but too diverse interests and perspectives might } \\
\text { lead to conflict and difficulties in finding common ground. A } \\
\text { common pitfall, on one hand, is an incomplete configuration of } \\
\text { problem owners and/or knowledge providers. Alternatively, } \\
\text { conflicting parties may easily get stuck in a zero-sum game and } \\
\text { feel reluctant to find common ground, mutual gains, and joint } \\
\text { solutions. }\end{array}$ \\
\hline Social learning & $\begin{array}{l}\text { Social learning processes at individual and group levels play a } \\
\text { central role in co-creation. Examples of social learning are new } \\
\text { or adjusted meanings about problems, new technology, social } \\
\text { innovations, and societal developments (Sol et al. 2018). A } \\
\text { social learning process cannot be divorced from the social } \\
\text { context in which it takes place (e.g. see Lave and Wenger } \\
\text { 1991). This means that individuals learn by taking part in } \\
\text { practice and gradually shift more to the core of the process. } \\
\text { However, the practice also influences individuals thoughts and } \\
\text { actions, which is common to the structure-agency debate. As } \\
\text { Argyris and Schön (1996) have presented, changing values is } \\
\text { far more difficult than changing practices since individuals tend } \\
\text { to avoid challenging established values. }\end{array}$ \\
\hline Iterative learning cycles & $\begin{array}{l}\text { Iterative learning cycles usually require longer trajectories of } \\
\text { co-creation with sufficient time for reflexive monitoring, } \\
\text { evaluation of interventions, and translating those lessons into a } \\
\text { new cycle of 'plan-do-evaluate-respond'. A lack of reflexive } \\
\text { monitoring (skills) and participation fatigue are common } \\
\text { pitfalls. Small wins and good personal relations help to keep } \\
\text { people on board for an extended period of time. }\end{array}$ \\
\hline
\end{tabular}


Table 4.5 (continued)

Principle of co-creation Shared ownership
Explanation and potential pitfalls

Shared ownership of the process and produced knowledge and outputs determines to what extent participants are willing to cooperate, contribute, share knowledge and follow-up, and implement collective actions or results of the co-creation trajectory. This relates to knowledge management, equal access to and sharing of information and know-how, intellectual property rights (IPRs), and responsibility for maintaining confidentiality (e.g. in case of Chatham House rules), which are all factors that can limit or support a collaborative environment.

Expectation management

Expectation management requires transparency about the process, time-planning, rules of the game (e.g. decisionmaking procedures or Chatham House rules), different roles, ownership, expected results, and follow-up.

Path dependency

Human behaviour gets shaped to a large extent by routines resulting from choices made in the past and institutional structures. This path dependency is a reason for institutional stability since institutional pressures force organizations to adopt similar practices or structures to gain legitimacy and support (DiMaggio and Powell 1983, 2000). As a result, these institutions can become firmly rooted in taken-for-granted rules, norms, and routines (Seo and Creed 2002). As such, path dependency may limit creativity and out-of-the-box thinking in a co-creation trajectory. On the other hand, the disqualification of 'old' frames of reference-by excluding (too easily) participants who adhere to dogmas, standard practices, or rules of behaviour-could limit equal participation. By emphasizing the historical and contextual systematic character of former rules of interaction it is possible to respect the involved participants and prevent disqualification of their 'old' frames of reference (valuation). This, in turn, might remove the defensive reactions that usually contribute particularly to locking up the existing frame even more firmly. New forms of value make it possible to expand the partnership.

Power of imagination A tangible and joint vision could serve as a vehicle to identify and create shared and common values during the co-creation trajectory, which is an important requirement to hold actor coalitions together. The ability to form mental pictures or ideas in the minds of participants is perhaps the most powerful tool for co-creation and could be stimulated by methods that support imagination and visualization of a shared future.

Institutional work
Co-creation activities, especially those with transformative impacts, require new partnership, agreements, standards, and activities aimed at adjusting formal and informal institutions. 
Open Access This chapter is licensed under the terms of the Creative Commons Attribution 4.0 International License (http://creativecommons.org/licenses/by/4.0/), which permits use, sharing, adaptation, distribution and reproduction in any medium or format, as long as you give appropriate credit to the original author(s) and the source, provide a link to the Creative Commons license and indicate if changes were made.

The images or other third party material in this chapter are included in the chapter's Creative Commons license, unless indicated otherwise in a credit line to the material. If material is not included in the chapter's Creative Commons license and your intended use is not permitted by statutory regulation or exceeds the permitted use, you will need to obtain permission directly from the copyright holder.

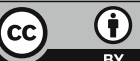

